Kansas State University Libraries

New Prairie Press

\title{
An Experiential Approach to Mentoring Academic Leaders: Review, Practice, Report
}

Julie A. Ray

Southeast Missouri State University, jaray@semo.edu

Victor R. Wilburn

Southeast Missouri State University, vwilburn@semo.edu

Melissa Odegard-Koester

Southeast Missouri State University, Modegard@semo.edu

Jeremy Ball

Southeast Missouri State University, jball@semo.edu

See next page for additional authors

Follow this and additional works at: https://newprairiepress.org/accp

Part of the Educational Leadership Commons, and the Higher Education Administration Commons (c) (i) (2)

This work is licensed under a Creative Commons Attribution-Share Alike 4.0 License.

\section{Recommended Citation}

Ray, J., Wilburn, V., Odegard-Koester, M, \& Ball, J. (2018, February). An Experiential Approach to Mentoring Academic Leaders: Review, Practice, Report. Paper presented at the Academic Chairpersons Conference, Orlando, FL.

This Event is brought to you for free and open access by the Conferences at New Prairie Press. It has been accepted for inclusion in Academic Chairpersons Conference Proceedings by an authorized administrator of New Prairie Press. For more information, please contact cads@k-state.edu. 


\section{Presenter Information}

Julie A. Ray, Victor R. Wilburn, Melissa Odegard-Koester, and Jeremy Ball 
An Experiential Approach to Mentoring Academic Leaders: Review, Practice, Report

\section{Session Description}

There is frequent turnover in the department chair position, requiring some type of mentoring for new chairs each year. Additionally, veteran chairs often report receiving little support in developing their own leadership skills. This session will present the structure of the Academic Leadership Development program at a Midwestern regional university that was designed to address these problems. This program includes a summer book study, an orientation session for new chairs in August with an introduction to a newly developed department chairs handbook, and monthly meetings throughout the academic year, led by different experienced chairs on topics pertinent to the academic calendar. For example, a fall meeting topic is recruiting and hiring quality faculty. These monthly meetings are open to all department chairs. This program emphasizes an experiential process that enables new department chairs to experience insightful information in the company of seasoned colleagues. Together best practices and realistic challenges are discussed and practical activities are suggested for leaders to immediately implement. In this program, leaders are developed through the processes of review, time to practice the new knowledge, and report observations in a supportive group setting. Additionally, library resources specific to academic leadership and the department chair position were purchased for the university library and a common website was created for chairs to upload any journal articles or other resources they found helpful in the development of their leadership skills. The Provost's office funded this program and also agreed to sponsor an annual department chairs' leadership professional development session with an expert consultant.

The presentation will be given by two veteran chairs who helped develop the program and two new department chairs who participated in the program. The perspectives of both experienced and new faculty will enrich the presentation by sharing the experiences and perspectives of all participants in the program. Additionally, conference attendees will be asked to share any mentoring or leadership development practices at their own institution and to consider how they can apply these ideas in their own setting. Recommendations will be given from lessons learned by the presenters in implementing this program, including the monthly topics, library resources, and books used for the summer book study. After attending this session, participants will be able to implement a leadership development program in their own setting, strengthening the knowledge and skills of their department chairs. 